

-Jurnal El-Qanuny

Volume 4 Nomor 2 Edisi Juli-Desember 2018

\title{
PERCERAIAN MENURUT KOMPILASI HUKUM ISLAM (KHI) DAN FIQH
}

\author{
Oleh \\ Muhammad Arsad Nasution \\ Dosen Fakultas Syariah dan Ilmu Hukum IAIN Padangsidimpuan \\ Email: muhammadarsadnst@iain-padangsidimpuan.ac.id
}

\begin{abstract}
Abstrac
This paper tells about divorce, even though it is permissible in Islamic law but it is an act that is hated by Allah Almighty. This solution is given if there is no way out anymore to solve the problems that occur between husband and wife in their household. In the process of implementation there is a dualism of understanding in society. One side of divorce or thalak is the husband's right so he can freely drop it whenever and wherever he wants. This is done, of course, after careful deliberation and peaceful efforts by both husband and wife families. Such provisions are found in the fiqh of fiqh of the Imam of the sect one of which is the fiqh of the Imam Shafi'i sect. Fall of thalak like this is considered legitimate by people who have long held the understanding of the Imam of his school.
\end{abstract}

Kata Kunci; Perceraian, Menurut, KHI, dan Fiqh

\section{A. Pendahuluan}

Perceraian walaupun dibolehkan dalam hukum Islam akan tetapi merupakan perbuatan yang sangat dibenci oleh Allah swt. Solusi ini diberikan apabila tidak ada jalan keluar lagi untuk menyelesaikan persoalan yang terjadi antara suami isteri dalam sebuah rumah tangga mereka. Dalam proses pelaksanaannya terjadi dualisme pemahaman dalam masyarakat. Satu sisi perceraian atau thalak merupakan hak suami sehingga ia dapat bebas menjatuhkannya kapan dan dimana saja ia kehendaki. Hal ini dilakukan tentu saja setelah melakukan berbagai pertimbangan yang matang dan sudah dilakukan upaya damai oleh kedua pihak keluarga suami isteri. Ketentuan seperti ini dijumpai dalam fiqh-fiqh imam mazhab salah satunya adalah fiqh mazhab Imam syafieci. Penjatuhan thalak seperti ini dianggap sah oleh masyarakat yang telah lama memegang pemahaman imam mazhabnya.

Pemerintah menetapkan proses thalak berdasarkan prosedur sidang di Pengadilan Agama. Proses thalak secara mandiri oleh suami ditertibkan oleh pemerintah dengan melalui proses sidang dipengadilan Agama. Proses seperti ini perlu dilakukan menurut pemerintah supaya tidak terjadi upaya sewenang-wenang oleh salah satu pihak terutama pihak suami. Pemerintah dengan tegas menyatakan "Perceraian hanya dapat dilakukan di depan sidang Pengadilan Agama setelah Pengadilan Agama tersebut berusaha dan tidak berhasil mendamaikan kedua belah pihak “. Pernyataan pemerintah ini seolah-olah mengatakan 


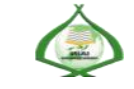

Volume 4 Nomor 2 Edisi Juli-Desember 2018

perceraian hanya sah apabila dilakukan setelah melalui proses sidang di depan Pengadilan Agama. Persoalan kemudian muncul bagaimana perceraian yang dilakukan tidak di depan sidang Pengadilan Agama hanya dilakukan secara fiqh. Bagaimanakah perceraian menurut Kompilasi Hukum Islam (KHI) sebagai salah satu peraturan pemerintah dan bagaimana pula perceraian menurut fiqh-fiqh imam mazhab. Makalah yang sederhana ini akan mencoba menguraikan persoalan ini dengan pendekatan analisis komparatif antara KHI di satu sisi, fiqh imam mazhab dalam hal ini fiqh Imam Syafie $i$ di sisi yang lain. Salah satu kitab yang di analsis adalah kitab fiqh Kifayatul Akhyar fi Halli Ghayatil Ikhtiyar oleh Imam Taqiyuddin Abi Bakar bin Muhammad al-Husainy al-Hashany al-Dimasqy al-Syafiei.

\section{B. Perceraian Menurut Kompilasi Hukum Islam (KHI)}

1. Pengertian Perceraian

Didalam Kompilasi Hukum Islam (KHI) tidak diatur mengenai pengertian perceraian tetapi hal-hal mengenai perceraian telah diatur dalam pasal 113 sampai dengan pasal 148 Kompilasi Hukum Islam (KHI). Dengan melihat isi pasal-pasal tersebut dapat diketahui bahwa prosedur bercerai tidak mudah, karena harus memiliki alasan-alasan yang kuat dan alasan-alasan tersebut harus benar-benar menurut hukum. Hal ini ditegaskan dalam pasal 115 Kompilasi Hukum Islam (KHI) yang isinya sebagai berikut : "Perceraian hanya dapat dilakukan didepan sidang Pengadilan setelah Pengadilan yang tersebut berusaha dan tidak berhasil mendamaikan kedua belah pihak." Berdasarkan Kompilasi Hukum Islam (KHI) Pasal 115 seperti yang termaktub diatas maka yang dimaksud dengan perceraian perspektif Kompilasi Hukum Islam (KHI) adalah proses pengucapan ikrar talak yang harus dilakukan didepan persidangan dan disaksikan oleh para hakim Pengadilan Agama. Apabila pengucapan ikrar talak itu dilakukan diluar persidangan, maka talak tersebut merupakan talak liar yang dianggap tidak sah dan tidak memiliki kekuatan hukum yang mengikat.

2. Bentuk-bentuk Perceraian ${ }^{1}$

a. Perkara Fasakh

Perkara fasakh adalah suatu perkara perceraian yang diputus oleh hakim atas gugatan istri. alasan utamanya bukan karena percekcokan suami-istri tersebut, tetapi karena suatu hambatan, kendala tertentu yang mengakibatkan tujuan perkawinan tidak terwujud, misalnya karena: walaupun perkawinan sudah cukup lama, tetapi belum juga mendapat keturunan, mungkin karena "kesalahan" salah satu pihak mandul. 
Alasan perceraian itu mungkin juga karena salah satu pihak menjadi gila, impoten dan semacamnya atau karena salah satu pihak dihukum untuk waktu yang lama. Karena salah satu alasan tersebut diatas, hakim akan mengabulkan gugatan perceraian yang demikian disebut perkara fasakh termasuk dalam jenis talak ba'insughro.

b. PerkaraTaqlîk Talâk

Perceraian berupa taqlik talak lazim juga disebut sebagai talak yang digantungkan. Permohonan perkara ini atas kehandak pihak istri dengan memohon agar Pengadilan Agama menetaapkan "syarat talak yang digantungkan sudah ada", yaitu suami telah melanggar janji-janji yang diucapkan sesaat setela hijab-kabul. Sebagaimana biasanya dalam pernikahan orang-orang Islam, setelah selesai upacara ijab-kabul ("penyerahan" pengantin wanita melalui walinya dan"penerimaan" oleh pengantin pria), pengantin laki-laki yang mengucapkan janji-janji yang sehubungan dengan jaminan terhadap perkawinan. Misalnya suami berjanji tidak akan menganiaya atau berjanji tidak akan meninggalkan isteri selama dua tahun berturut-turut, dan sebagainya. Apabila salah satu dari janji tersebut dilanggar maka syarat taqliktalak/talak yang yang digantungkan telah terpenuhi maka istri dapat memohon putusan perceraian pada pengadilan yang lazim dikenal sebagai taklik talak

\section{c. Perkara Syiqâq}

Arti katanya: Perpecahan, sedangkan menurut ajaran Islam sebagaimana yang disebut dalam Al-Qurean Surat An-Nisae ayat 35, yang isinya apabila terjadi perselisihan antara suami-istri, hendaknyakeluarga kedua belah pihak menunjuk dan mengangkat hakam-hakam pendamai bagi suami isteri tersebut. Di Negara Indonesia ini kelanjutan maksud hakam-hakam tersebut telah terbentuk lembaga resmi yaitu Badan Penasehat Perkawinan, Perselisihan, dan Perceraian (BP 4),yang bertugas untuk mendamaikan sesuai dengan pasal pasal 31 PP No. 9 tahun1975. Dalam praktek, jasa atau nasihat BP-4 ini sering diminta oleh Hakim Peradilan Agama dalam menangani perkara perceraian. apabila BP-4 tidak berhasil mendamaikan, setelah setelah masalah itu kembali dihadapan Hakim Pengadilan Agama ini, disini hakim masih berkewajiban lagi untuk berupaya mendamaikan sesuai dengan ketentuan pasal 31 PP No.9 tahun 1975. Apabila upaya perdamaian itu berhasil, baik yang dilakukan oleh BP-4 maupun oleh Hakim Pengadilan akan dibuat akta perdamaian, denagn konsekwensi apabila di antara kedua suami-istri itu timbul lagi percekcokan dengan alasan percekcokan dengan alasan percekcokan yeng telah berhasil didamaikan, akan 
ditolak atau tidak boleh lagi sebagai alasan untuk melakukan perceraian. Perceraian karena percekcokan yang terus menerus terjadi, tergolong sebagai cerai gugatan/syiqaq.

d. Perkara Li'ân

Asal kata la'na: kutuk, sedangkan dalam Qur'ean surat 24 ayat 6 sampai dengan 9. Perceraian berdasarkan gugatan dari suami dengan alasan atau tuduhan istri melakukan perzinahan, tanpa saksi maupun bukti yang cukup disebut perkara perceraian karenali'an. Proses pemeriksaan perkara itu dari suami-istri, dilakukan dengan kewajiban masing-masing mengucapkan sumpah sebanyak 5 kali. Pelaksanaansumpah itu, dengan mendahulukan pihak yang menuduh mengucapkan sumpah"Dengan nama Allah menyatakan istrinya telah melakukan zina", diucapkan sebanyak 4 kali. Dan pada sumpah yang kelima, ia (suami) mengucapkan sumpah: “Apabila tidak benar, apa yang saya tuduhkan akan menerima segala kutuk dan laknat Allah. Sebaliknya pihak istri wajib mengucapkan sumpahnya atas nama Allah sebanyak 4 kali sebagai bantahan terhadap tuduhan suaminya. Pada sumpah kelima ia mengatakan akan menerima segala kutuk dan laknat Allah, bila ia benar telah melakukan zina yang dituduhkan oleh suaminya. Proses perkara demikian disebut PerkaraLi'an. Dapat ditambahkan bahwa sebagian ahli hukum berpendapat, bahwa pengadilan Agama tidak dapat memeriksa perkara Li'an, karena tuduhan perzinahan menyangkut pembuktian pidana dan seharusnya diperiksa oleh Pengadilan Negeri. Akan tetapi, sebagian lagi berpendapat bahwa PengadilanAgama tersebut berwenang memeriksa perkaraLi'an, karena dalam pemeriksaan. Pengadilan Agama tersebut tidak sampai pada penilaian benar tidaknya apa yang dituduhkan. Dengan kata lain tidak memeriksa unsur pidana materiilnya.

e. Perkara khuluk

Khuluk adalah perceraian yang didasarkan pada gugatan pihak istri. Apabila Hakim mengabulkannya, penggugat (istri) berkewajiban membayar iwadl, dan talaknya tergolong talak ba 'in. Hal tersebut hanya boleh dilakukan pada dua keadaan yakni jika dikhawatirkan salah satu dari keduanya tidak melaksanakan ajaran-ajaran Allah yakni sesuatu yang difardhukan oleh Allah dalam pernikahan. Yang kedua, yakni sumpah untuk talak tiga kali atas satu permasalahan yang wajib baginya maka boleh mengabulkan khuluk wanita tersebut. Kemudian melaksanakan sumpah tersebut karena hanya bisa melakukan tindakan yang pertama maka diperbolehkan. 


\section{Penyebab Perceraian}

Perceraian sebagai penyebab putusnya perkawinan dapat terjadi karena berbagai hal tertentu yang secara umum menurut KHI. dapat dikelompokkan pada tiga faktor yaitu: ${ }^{2}$

a. Kematian

Salah satu pihak meninggalkan pihak yang lain selama 2 (dua) tahun berturutturut tanpa izin pihak lain dan tanpa alasan yang sah atau hal lain diluar kemampuannya, maka untuk pengajuan gugatannya, diajukan setelah lampau tahun terhitung sejak tergugat meninggalkan rumah, agar gugatannya diterima maka perlu dibuktikan bahwa tergugat menyatakan atau menunjukkan sikap tidak mau lagi kembali kerumah kediaman bersama.(lihat PP. No. 9/1975 Pasal19 huruf (h).

b. Perceraian

c. Atas putusan Pengadilan

Putusnya perkawinan yang disebabkan karena perceraian dapat terjadi karena talak atau berdasarkan gugatan perceraian. Perceraian hanya dapat dilakukan di depan sidang Pengadilan Agama setelah Pengadilan Agama tersebut berusaha dan tidak berhasil mendamaikan kedua belah pihak. Perceraian dapat terjadi karena alasan atau alasan-alasan:

1) salah satu pihak berbuat zina atau menjadi pemabuk, pemadat, penjudi dan lain sebagainya yang sukar disembuhkan;

2) salah satu pihak meninggalkan pihak lain selama 2 (dua) tahun berturut-turut tanpa izin pihak lain dan tanpa alasan yang sah atau karena hal lain diluar kemampuannya;

3) salah satu pihak mendapat hukuman penjara 5 (lima) tahun atau hukuman yang lebih berat setelah perkawinan berlangsung;

4) salah satu pihak melakukan kekejaman atau penganiayaan berat yang membahayakan pihak lain;

5) salah satu pihak mendapat cacat badan atau penyakit dengan akibat tidak dapat menjalankan kewajibannya sebagai suami atau isteri;

6) antara suami dan isteri terus menerus terjadi perselisihan dan pertengkaran dan tidak ada harapan akan hidup rukun lagi dalam rumah tangga;

7) Suami melanggar taklik talak;

8) peralihan agama atau murtad yang menyebabkan terjadinya ketidak rukunan dalam rumah tangga. 


\section{C}

4. Perceraian dengan sebab thalak

Talak adalah ikrar suami di hadapan sidang Pengadilan Agama yang menjadi salah satu sebab putusnya perkawinan, dengan cara sebagaimana dimaksud di atas. Talak Raj'I adalah talak kesatu atau kedua, dimana suami berhak rujuk selama isteri dalam masa iddah. Talak Ba in Shughraa adalah talak yang tidak boleh dirujuk tapi boleh akad nikah baru dengan bekas suaminya meskipun dalam iddah. Talak Ba`in Shughra adalah :

a. thalak yang terjadi qabla al dukhul;

b. thalak dengan tebusan atahu khuluk;

c. thalak yang dijatuhkan oleh Pengadilan Agama.

Thalak Ba in Kubraa adalah talak yang terjadi untuk ketiga kalinya. Talak jenis ini tidak dapat dirujuk dan tidak dapat dinikahkan kembali, kecuali apabila pernikahan itu dilakukan setelah bekas isteri, menikah degan orang lain dan kemudian terjadi perceraian ba`da al dukhul dan habis masa iddahnya. Talak sunny adalah talak yang dibolehkan yaitu talak yang dijatuhkan terhadap isteri yang sedang suci dan tidak dicampuri dalam waktu suci tersebut. Talak bid'I adalah thalak yang dilarang, yaitu talak yang dijatuhkan pada waktu isteri dalam keadaan haid atau isteri dalam keadaan suci tapi sudah dicampuri pada waktu suci tersebut. Perceraian itu terjadi terhitung pada saat perceraian itu dinyatakan di depan sidang pengadilan.

5. Perceraian dengan li`an

Li`an menyebabkan putusnya perkawinan antara suami isteri untuk selama-lamnya. Li'an terjadi karena suami menuduh isteri berbuat zinah dan atau mengingkari anak dalam kandungan atau yang sudah lahir dari isterinya, sedangkan isteri menolak tuduhan dan atau pengingkaran tersebut. Tata cara li`an diatur sebagai berikut :

a. Suami bersumpah empat kali dengan kata tuduhan zina dan atau pengingkaran anak tersebut diikuti sumpah kelima dengan kata-kata "laknat Allah atas dirinya apabila tuduhan dan atau pengingkaran tersebut dusta;

b. Isteri menolak tuduhan dan atau pengingkaran gtersebut dengan sumpah empat kali dengan kata "tuduhan dan atau pengingkaran tersebut tidak benar", diikuti sumpah kelima dengan kata-kata murka Allah atas dirinya :tuduhan dan atau pengingkaran tersebut benar";

c. tata cara pada huruf a dan huruf b tersebut merupakan satu kesatuan yang tak terpisahkan; 


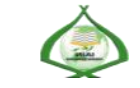

d. apabila tata cara huruf a tidak diikuti dengan tata cara huruf b, maka dianggap tidak terjadi li an.

Li`an hanya sah apabila dilakukann di hadapan sidang Pengadilan Agama.

6. Tata Cara Perceraian

Seorang suami yang akan menjatuhkan talak kepada isterinya mengajukan permohonan baik lisan maupun tertulis kepada Pengadilan Agama yang mewilayahi tempat tinggal isteri disertai dengan alasan serta meminta agar diadakan sidang untuk keperluan itu.Pengadilan Agama dapat mengabulkan atau menolak permohonan tersebut, dan terhadap keputusan tersebut dapat diminta upaya hukum banding dan kasasi. Pengadilan agama yang bersangkutan mempelajari permohonan dimaksud dan dalam waktu selambat-lambatnya tiga puluh hari memanggil pemohon dan isterinya untuk meminta penjelasan tentang segala sesuatu yang berhubungan dengan maksud menjatuhkan talak. Setelah Pengadilan Agama tidak berhasil menashati kedua belah pihak danternyata cukup alasan untuk menjatuhkan talak serta yang bersangkutan tidak mungkin lagihidup rukun dalamrumah tangga, pengadilan Agama menjatuhkan keputusannya tentang izin bagi suami untuk mengikrarkan talak. Setelah keputusannya mempunyai kekeutan hukum tetap suami mengikrarkan talaknya di depan sidang Pengadilan Agama, dihadiri oleh isteri atau kuasanya.

Bila suami tidak mengucapkan ikrar talak dalam tempo 6 (enam) bulah terhitung sejak putusan Pengadilan Agama tentang izin ikrar talak baginya mempunyai kekuatanhukum yang tetap maka hak suami untuk mengikrarkan talak gugur dan ikatan perkawinan yang tetap utuh. Setelah sidang penyaksian ikrar talak Pengadilan Agama membuat penetapan tentang terjadinya Talak rangkap empat yang merupakan bjukti perceraian baki bekas suami dan isteri.

Helai pertama beserta surat ikrar talak dikirimkan kepada Pegawai Pencatat Nikah yang mewilayahi tempat tinggal suami untuk diadakan pencatatan, helai kedua dan ketiga masingmasing diberikan kepada suami isteri dan helai keempat disimpan oleh Pengadilan Agama.

Gugatan perceraian diajukan oleh isteri atau kuasanya pada Pengadilan Agama,yang daerah hukumnya mewilayahi tempat tinggal penggugat kecuali isteri meninggalkan tempat kediaman bersama tanpa izin suami. Dalam hal tergugat bertempat kediaman diluar negeri, Ketua Pengadilan Agama memberitahukan gugatan tersebut kepada tergugat melalui perwakilan Republik Indonesia setempat. 
Gugatan perceraian karena alasan salah satu pihak meninggalkan pihak lain selama 2 (dua) tahun berturut-turut tanpa izin pihak lain dan tanpa alasan yang sah atau karena hal lain diluar kemampuannya, dapat diajukan setelah lampau 2 (dua) tahun terhitung sejak tergugat meninggalkan gugatan meninggalkan rumah. Gugatan dapat diterima apabila tergugat menyatakan atau menunjukkan sikap tidak mau lagi kembali ke rumah kediaman besama. Gugatan perceraian karena alasan antara suami dan isteri terus menerus terjadi perselisihan dan pertengkaran dan tidak ada harapan akan hidup rukun lagi dalam rumah tangga, dapat diterima apabila telah cukup jelas bagi Pengadilan Agama mengenai sebab-sebab perselisihan dan pertengkaran itu dan setelah mendengar pihak keluarga serta orang-orang yang dekat dengan suami isteri tersebut. Gugatan perceraraian karena alsan suami mendapat hukuman penjara 5 (lima) tahun atau hukuman yang lebih berat, maka untuk mendapatkanputusan perceraian sebagai bukti penggugat cukup menyapaikan salinan putusan Pengadilan yang memutuskan perkara disertai keterangan yang menyatakan bahwa putusan itu telah mempunyai kekuatan hukum yang tetap. Selama berlangsungya gugatan perceraian atas permohonan penggugat atau tergugat berdasarkan pertimbangan bahaya yang mingkin ditimbulkan, Penghadilan Agama dapat mengizinkan suami isteri tersebut untuk tidak tinggal dalam satu rumah. Selama berlangsungnya gugatan perceraian atas permohonan penggugat atau tergugat, Pengadilan Agama dapat :

a. menentukan nafkah yang harus ditanggung oleh suami;

b. menentukan hal-hal yang perlu untuk menjamin terpeliharanya barang-barang yang menjadi hak bersama suami isteri atau barang-barang yang menjadi hak suami atau barang-barang yang menjadi hak isteri.

Gugatan perceraian gugur apabila suami atau isteri meninggal sebelum adanya putusan pengadilan Agama mengenai gugatan perceraian itu. Apabila tempat kediaman tergugat tidak jelas atau tergugat tidak mempunyai tempat kediaman yang tetap, panggilan dilakukan dengan cara menempelkan gugatanpada papan pengumuman di Pengadilan Agama dan mengumumkannya melalui satu atau bebrapa surat kabar atau mass media lain yang ditetapkan oleh Pengadilan Agama. Pengumuman melalui surat kabar atau surat-surat kabar atau mass media tersebut ayat dilakukan sebanyak 2 (dua) kali dengan tenggang waktu satu bulan antara pengumuman pertama dan kedua. Tenggang waktu antara penggilan terakhir dengan persidangan ditetapkan sejurangkurangnya 3 (tiga) bulan. Dalam hal sudah dilakukan pemanggilan tergugat atau 
kuasanya tetap tidak hadir, gugatan diterima tanpa hadirnya tergugat, kecuali apabila gugatan itu tanpa hak atau tidak beralasan.

Pemeriksaan gugatan perceraian dilakukan oleh hakim selambat-lambatnya 30 (tiga puluh) hari setelah diterimanya berkas atau surat gugatan perceraian. Dalam menetapkan waktu sidang gugatan perceraian perlu diperhatian tenyang waktu pemanggilan dan diterimanya panggilan tersebut oleh penggugat maupun tergugat atau kuasa mereka. Apabila tergughat berada dalam keadaan salah satu pihak meninggalkan pihak lain selama 2 (dua) tahun berturut-turut tanpa izin pihak lain dan tanpa alasan yang sah atau karena hal lain diluar kemampuannya, sidang pemeriksaan gugatan perceraian ditetapkan sekurang-kurangnya 6 (enam) bulan terhitung sejak dimasukkanya gugatan perceraian pada Kepaniteraan Pengadilan Agama.

Pada sidang pemeriksaan gugatan perceraian, suami isteri datang sendiri atau mewakilkan kepada kuasanya. Dalam hal suami atau isteri mewakilkan, untuk kepentingan pemeriksaan Hakim dapat memerintahkan yang bersangkutan untuk hadir sendiri. Dalam pemeriksaan gugatan perceraian Hakim berusaha mendamaikan kedua belah pihak. Selama perkara belum diputuskan usaha mendamaikan dapat dilakukan pada setiap sidang pemeriksaan. Apabila terjadi pedamaian, maka tidak dapat diajukan gugatan perceraian baru berdasarkan alasan atau alasan-alasan yang ada sebelum perdamaian dan telah diketahui oleh penggugat pada waktu dicapainya perdamaian. Apabila tidak dicapai perdamaian, pemeriksaan gugatan perceraian dilakukan dalam sidang tertutup. Putusan mengenai gugatan perceraian dilakukan dalam sidang terbuka. Suatu perceraian dianggap terjadi beserta akibat-akibatnya terhitung sejak jatuhnya putusan Pengadilan Agama yang telah mempuntai kekuatan hukum yang tetap. Setelah perkara perceraian itu diputuskan,maka panitera Pengadilan Agama menyampaikan salinan surat putusan tersebut kepada suami isteri atau kuasanya dengan menarik Kutipan Akta Nikah dari masing-masing yang bersangkutan. Panitera Pengadilan Agama berkewajiban mengirimkan satu helai salinan putusan Pengadilan Agama yang telah mempunyai kekuatan hukum yang tetap tanpa bermaterai kepada Pegawai Pencatat Nikah yang mewilayahi tempat tinggal isteri untuk diadakan pencatatan. Panitera Pengadilan Agama mengirimkan surat Keterangan kepada masing-masing suami isteri atau kuasanya bahwa putusan telah mempunyai kekuatan hukum yang tetap dan merupakan bukti perceraian bagi suami dan bekas istri. Panitera Pengadilan Agama membuat catatan dalam ruang yang tesedia pada Kutipan Akta Nikah yang bersangkutan 
bahwa mereka telah bercerai. Catatan tersebut berisi tempat terjadinya perceraian, tanggal perceraian, nomor dan tanggal surat putusan serta tanda tangan panitera. Satu helai salinan putusan Pengadilan Agama dikirimkan kepada Pegawai Pencatat Nikah yang mewilayahi tempat perkawinan dilangsungkan dan bagi perkawinan yang dilangsungkan di luar Negeri Salinan itu disampaikan kepada Pegawai Pencatat Nikah Jakarta. Kelalaian mengirimkan salinan putusan menjadi tanggungjawab Panitera yang bersangkutan, apabila yang demikian itu mengakibatkan kerugian bagi bekas suami atau isteri atau keduanya.

Seorang isteri yang mengajukan gugatan perceraian dengan jalan khuluk, menyanpaikan permohonannya kepada Pengadilan Agama yang mewilayahi tempat tinggalnya disertai alasan atau lasan-alasannya. Pengadilan Agama selambat-lambatnya satu bulan memanggil isteri dan suaminya untuk didengar keterangannya masing-masing. Dalam persidangan tersebut Pengadilan Agama memberikan penjelasan tentang akibat khuluk, dan memberikan nasehat-nasehatnya. Setelah kedua belah pihak sepakat tentang besarnya iwadl atau tebusan, maka Pengadilan Agama memberikan penetapan tentang izin bagi suami untuk mengikrarkan talaknya disepan sidang Pengadilan Agama. Terhadap penetapan itu tidak dapat dilakukan upaya banding dan kasasi. Dalam hal tidak tercapai kesepakatan tentang besarnya tebusan atau iwadh Pengadilan Agama memeriksa dan memutuskan sebagai perkara biasa.

\section{Perceraian Menurut Kitab Fiqh Kifayatul Akhyar}

a. Pasal tentang khulu'

Khulu' dibolehkan dengan 'iwad yang tertentu di dasarkan pada al-Qur'an pada surat al-Baqarah yang berbunyi "Kecuali kalau keduanya khawatir tidak akan dapat menjalankan hukum-hukum Allah. jika kamu khawatir bahwa keduanya (suami isteri) tidak dapat menjalankan hukum-hukum Allah, Maka tidak ada dosa atas keduanya tentang bayaran yang diberikan oleh isteri untuk menebus dirinya...”. \{al-Baqarah/2: 229\}. Hadits Nabi Muhammad SAW, dari Ibn Abbas ra. bahwa isteri Sabit bin Qais menjumpai Nabi saw. ia berkata:"Wahai Rasulullah Sabit bin Qais aku tidak bermaksud bercerai dengannya karena akhlaknya dan juga agamanya, akan tetapi aku benci kekufuran dalam agama Islam". Nabi saw bersabda: "Apakah kau mau mengembalikan kebunnya”. Isterinya berkata:” ya “. Maka nabi kemudian bersabda: “Ambil kembali kebunmu dan thalak isterimu dengan thalak satu". Apabila terjadi khulu' maka suami tidak ada hak untuk merujuki isterinya. 
b. Pasal tentang Thalak

Thalak itu ada dua bentuk yaitu sharih dan kinayah., Rukun thalak yaitu adanya lafaz baik sharih maupun kinayah. Lafaz syarih menggunakan akta thlak dan faraqa karena kedua kata ini terdapat dalam al-Qurean dan Sunnah. Lafaz kinayah yaitu seluruh lafaz yang mengandung makna thalak yang disertai dengan niat. Adanya thalak dengan kinayah karena adanya hadits bahwa Umar ra. berkata kepada seorang laki-laki yang berkata kepada isterinya "talimu berada di atasmu, aku bersumpah dengan tuhan anakmu ini". Umar berkata": Apakah ini kau maksudkan dengan menthalaknya, laki-laki itu berkata:" ia". Umar kemudian berkata: "Perkataanmu sesuai dengan kehendakmua".

Thalak terbagi dua bila dikaitkan dengan keadaan isteri yang dithalak yaitu sunnah apabila isteri dithalak dalam keadaan suci dan belim jima dan bid"eah apabila isteri dithalak dalam keadaan haid atau pada waktu suci tapi sudah dijima ${ }^{e e}$. Hak thalak bagi orang merdeka ada tiga thalak di dasarkan pada al-Qurean surat alBaqarah ayat 229, sedangkan untuk hamba hanya ada dua thalak didasarkan pada hadis Nabi Muhammad SAW "thalak seorrang hamba adalah dua thalak".

Thalak sah dengan menggantungkannya pada sifat atau syarat tertentu seperti seorang suami mengatakan kepada isterinya engkau terthalak jikaengkau menghendaki. Apabila seorang isteri menghnedakinya ia terthalak dengan sendirnya. Contoh lain seorang suami mengatakan: "engkau terthalak jika engkau berteman dengan sianu", maka isterinya akan terthalak jika ia melanggar syarat tersebut. Thalak tidak jatuh sebelum nikah, karena syarat thalak tersebut harus ada al-wilayah (kewenangan) untuk menjatuhkannya, kewenangan menjatuhkan thalak tidak ada sebelum menikah. Ada empat kelompok yang tidak jatuh thalaknya yaitu anak-anak, orang gila, orang tidur, dan orang yang dipaksa.

Jika seseorang menthalak isterinya satu atau dua maka ia dapat merujukinya sebelum habis masa iddahnya, apabila telah selesai masa iddahnya maka dilakukan nikah baru dan ia hanya berhak menjatuhkan thalak yang tersisa. Apabila seorang suami menthalak isterinya dengan thalak tiga maka isterinya tidak dapat kembali kepadanya kalau tidak lima syarat; habis masa iddahnya, menikah dengan laki-laki lain, bersetubuh dengan laki-laki tersebut, terjadi perceraian dengan laki-laki tersebut, dan habis masa iddahnya.

8. Analisis 
Uraian di atas menunjukkan bahwa percerain dari segi hukum materilnya tidak ada perbedaan antara KHI dengan fiqh Kifayatul Akhyar. Kompilasi Hukum Islam (KHI) menjelaskan perceraian dapat terjadi karena thalak, khuluk, dan lian, dalam kitab fiqh tersebut juga menjelaskan perceraian dapat terjadi karena thalak, khuluk, dan lieean. Selain itu kitab fiqh msih memperkenalkan zhihar dan ila' sebagai bentuk perceraian, namun dalam KHI ketentuan ini tidak diatur. Hal ini disebabkan pristiwa perceraian dengan cara ila' atau zhihar tidak dikenal dalam masyarakat Indonesia. Fiqh sebagai bentuk pemahaman hukum Islam yang disusun oleh ulama dari Timur Tengah memasukkan ila' dan zhihar sebagai bentuk upaya menceraikan oleh suami terhadap isteri, karena budaya ini mereka kenal dilingkungan masyarakat muslim Timur Tengan (budaya Arab).

Perceraian dari aspek hukum formilnya terdapat perbedaan antara KHI dengan kitab fiqh Kifayatul Akhyar. KHI hanya mengakui perceraian yang diproses di depan sidang Pengadilan Agama, sedangkan fiqh dalam kitab di atas tidak menyatakan adanya proses pengadilan dalam penjatuhan thalak. Perceraian yang dilakukan oleh suami dengan menjatuhkan thalak kepada isterinya dianggap sah dalam fiqh. Namun demikian fiqh imam mazhab tidak menguraikan thalak harus melalalui proses peradilan. Hal ini bukan berarti peroses perceraian pada saat sekarang ini yang paling tepat sesuai dengan aturan yang terdapat dalam fiqh. Peroses perceraian melalui pengadilan dianggap mempersempit hak suami menjatuhkan thalak dan mengakibatkan biaya yang berat. Penetapan perceraian melalui proses persidangan didasarkan pada kemaslahatan yaitu melindungi hak-hak prempuan. Dalam sumber yang sama dikatakan: ${ }^{3}$

$$
\text { فقبدقال أبـالصهباء ل بد هلال بن عباس :أما علمت أن الرحل كان إذا طلق امرأتاه ثالثاا }
$$

Artinya:

“Abu al-cahba' berkata kepada Ibnu Abbas: apa kamu tidak tahu bahwa suami yang menjatuhkan talak tiga sekaligus kepada isterinya sebelum ia campuri hanya dinyatakan jatuh talak satu di masa Rasul SAW, Abu Bakar dan dipermulaan pemerintahan Umar sendiri? Ibnu Abbas menjawab, ya benar adanya". 4

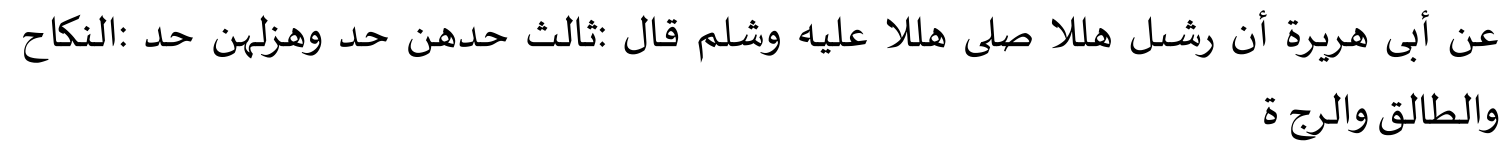

Artinya: 
"Dari Abu Hurairah, sesungguhnya Rasul SAW telah bersabda: ada tiga perkara menjadi terwujud, baik dengan sungguh-sungguh maupun main-main, yaitu: nikah, talak dan rujuk". 5

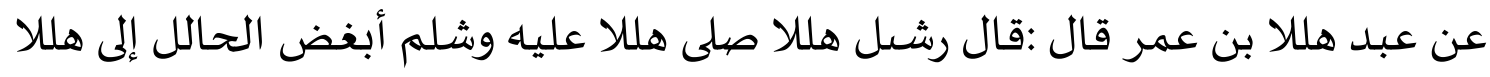

Di Indonesia ulama yang getol mempopulerkan "Fikih Indonesia" adalah TM. Hasbi Ash-Shiddieqy dan Hazairin.Perbedaan keduanya adalah Hazairin menulis tentang konsep hukum waris nasional dalam sebuah buku sehingga mudah diketahui dan dipelajari. Dalam pada itu Hasbi menulis gagasannya tentang fikih yang berkepribadian Indonesia secara 10 Abu Daud, Sunan Abi Daud, Juz. 2, cetakan ke 1,t.t:Dar al-Kitab al'Arabi, t.th, hlm. 2359 terpencar-pencar dalam beberapa buah buku dan artikel, sehingga memerlukan pelacakan dan ketekunan dalam mengkajinya.11 Fikih Indonesia dapat dikenali ciri-cirinya dalam produk hukum Islam seperti mengacu pada maslahat kekinian, mengkomodir kearifan lokal, menganut prinsip kompilasi dan menerima talfiq, mengdepankan metodologi hukum Islam yang rasional seperti maslahat mursalah dan istihsan, sadduzariah ${ }^{6}$ perkawinan menggunkan pencataan dan prosedur lainnya untuk penguatan akad perkawinan ${ }^{7}$

\section{Penutup}

Berdasarkan uraian di atas dapat disimpulkan bahwa perceraian melalui proses sidang pengadilan merupakan ijtihad para ulama Indonesia yang didasarkan pada kemaslahatan yang harus diwujudkan pada masa diterapkannya aturan tersebut.

Perceraian semstinya diproses melalui Pengadilan Agama agar perbuatan hukum ini dapat berjalan lebih adil dan lebih sempurna. Kitab-kitab sumber KHI, dimana dalam penelitian kitab-kitab fiqh ini tim proyek KHI bekerja sama dengan 7 IAIN yang tersebar di seluruh Indonesia untuk mengkaji dan dimintai pendapatnya, beserta argumentasi dan dalildalil hukumnya. Sebanyak 38 macam kitab fiqh dari berbagai madzhab dibagi kepada 7 IAIN dengan rincian sebagai berikut:

1. IAIN Arraniri Banda Aceh: Al BajurI, Fathul Mu'in, Syarqawi alat Tahrier, Mughnil Muhtaj, Nihayah Al MuhtaJ, dan Asy Syarqawi;

2. IAIN Syarif Hidayatullah Jakarta; ,Ianatut Thalibin, Tuhfah, Targhibul Musytag, Bulghat Al Salik, Syamsuri fil Faraidl, dan Al Mudawanah; 
3. IAIN Antasari Banjarmasin; Qalyabi/Mahalli, Fathul Wahab dengan Syarahnya,

Bidayatul Mujtahid, Al Umm, Bughytul Mustarsyidin, dan Aqiedah Wa al Syariah;

4. IAIN Sunan Kalijaga Yogyakarta; Al Muhalla, Al Wajiz, Fathul Qadier, Al Fiqhul ala Madzhabil Arbaan, dan Fiqhus Sunnah;

5. IAIN Sunan Ampel Surabaya; Kasyf Al Qina, Majmu atu Fatwi Ibn Taymiah, Qawaninus Syariah Lis Sayid Usman bin Yahya, Al Mughni, dan Al Hidayah Syarah Bidayah Taimiyah Mubtadi;

6. IAIN Alaudin Ujung Pandang; Qawanin Syar'iyah Lis Sayid Sudaqah Dakhlan, Nawab al Jalil, Al Muwatha, dan Hasyiah Syamsuddin Muh Irfan Dasuki;

7. IAIN Imam Bonjol Padang: Badal al Sannai, Tabyin al Haqaiq, Al Fatwa Al Hindiyah, Fathul Qadier, dan Nihayah.

\section{DAFTAR PUSTAKA}

Abdurrahman, Kompilasi Hukum Islam di Indonesia, Jakarta: Akademika Pressindo, 1992.

Muhammad Rawwas Qal'aji, Mausû̀at Fiqh Umar bin Khattab. Abu Daud, Sunan Abi Daud, Juz. 2, cetakan ke 1, t.t: Dar al-Kitab al-`Arabi, t.th.

Ibnu Majah, Sunan Ibni Majah, Juz. 1, t.t : Dar al-fikr, t.th.

Nouruzzaman Shiddieqy, Fiqh Indonesia Penggagas dan Gagasannya, cet ke 1, Yogyakarta: Pustaka Pelajar, 1997.

Masjkur Anhari, Usaha-usaha untuk Memberikan Kepastian Hukum dalam Perkawinan, Surabaya: Diantama, 2006.

Gunawan, Hendra,. Potret Perjalan Hukum Islam di Indonesia, Jurnal Al-Maqasid; Jurnal

Ilmu Kesyariahan dan Keperdataan Fakultas Syariah dan Ilmu Hukum IAIN Padangsidimpuan, Vol. 4 No. 1. Edisi Januari-Juli 2018.

http://agushairi.blogspot.com/2018/01/konsep-dasar-perceraian-perspektif.html?m=0

\section{End Note :}

${ }^{1}$ http://agushairi.blogspot.com/2018/01/konsep-dasar-perceraian-perspektif.html?m=0

${ }^{2}$ Abdurrahman, Kompilasi Hukum Islam di Indonesia, (Jakarta: Akademika Pressindo, 1992), hlm. 141.

${ }^{3}$ Muhammad Rawwas Qal'aji, Mausû`at Fiqh Umar bin Khattab, hlm. 487

${ }^{4}$ Abu Daud, Sunan Abi Daud, Juz. 2, (Cetakan ke 1,t.t:Dar al-Kitib al-`Arabi, t.th), hlm. 235

${ }^{5}$ Ibnu Majah, Sunan Ibni Majah, Juz. 1, (t.t : Dar al-fikr, t.th), hlm. 650.

${ }^{6}$ Nouruzzaman Shiddieqy, Fiqh Indonesia Penggagas dan Gagasannya, cet ke-1, (Yogyakarta: Pustaka Pelajar, 1997), hlm. 241.

${ }_{7}$ Masjkur Anhari, Usaha-usaha untuk Memberikan Kepastian Hukum dalam Perkawinan, (Sirabaya: Diantama, 2006), hlm., 5. 